\title{
イヌに抢ける肝切除後の膵内分泌系の変化について
}

\author{
京都大学医学部第 1 外科学教空 \\ 平野 鉄也 真辺 忠夫 山木健一郎 \\ 浅野昇 戸部 隆吉
}

\section{CHANGES OF ENDOCRINE PANCREAS AFTER \\ PARTIAL HEPATECTOMY IN DOGS}

\author{
Tetsuya HIRANO, Tadao MANABE, \\ Kenichiro YAMAKI, Noboru ASANO \\ and Takayoshi TOBE
}

First Department of Surgery, Faculty of Medicine, Kyoto University

肝切除後の肝再生過程での膵内分泌系の役割を解明する目的で，イヌにおいて40\%肝切除後経時的 に門脈血中膵ホルモンを測定するとともに経静脈的耐糖能検查と膵生検を施行し, 耐糖能および組織 学的に膵島とその構成要素である $\mathrm{A}, \mathrm{B}, \mathrm{D}$ 細胞の变化を観察した. 肝切除 2 日後門脈血中インスリン は $59 \%$ ，ソマトスタチンは $53 \%$ と有意に低下し，膵グルカゴンは $173 \%$ に上昇（いすれも $\mathrm{p}<0.05 ） し ，$ この傾向は約 1 週間持続した。膵島は肝切除 1 週間後有意に増大し, A, B, D 細胞は全てが 1.5 倍に 増大した。経静脈的而糖能検査による耐糖能は術後早期に低下し, 肝切除後の膵内分泌系における機 能と形態でのかい離が認められ, 肝切除後の肝膵相関の複雑な関連性が示唆された。

索引用語: 膵ホルモン, 膵島, 肝切除術, 肝膵相関

はじめに

肝と膵は門脈系によって連結されており, 臟器相関 の上からも密接な関連性をもっている, 一方, 肝切除 後の肝再生過程に括いては, 膵ホルモン, 特にインス リンとグルカゴンが hepatotrophic factor として重要 であることが以前より報告されている1) 3!.しかしな がら，それらの報告は主として肝切除後のごく早期の 変化で, しかも分離肝細胞による初代肝細胞培養を用 いた in vitroの系での研究4であり, 肝奶除後に, 肝・ 脺相関といら見地から数週間にわたり in vivoでの門 脈血中の膵ホルモンの変動や, 組織学的に膵島や酎糖 能の変化を観察した報告は少ない.今回，われわれは， イヌに颃いて肝切除後, 門脈血中の膵ホルモンの変動 を経静脈的耐糖能検査に㧍ける耐糖能の変化拉よび膵 島の組織学的変化とともに観察したので報告する.

$<1989$ 年 6 月 7 日受理>別刷請求先：真辺 忠夫 干606 京都市左京区聖護院川原町54 京都大学医学 部第 1 外科

\section{材料および方法}

体重 $12 \mathrm{~kg}$ から $14 \mathrm{~kg} の$ Beagle 成犬 4 頭に left lateral lobe および left central lobe の 2 葉を切除する左 側の約 $40 \%$ 肝切除術をペントバルビタール麻酔下に施 行し,

1. 術前より脾静脈の分枝より門脈本幹に插入留置 して扣いたカテーテルより，空腹覚醒時に，門脈血を 採取し, 肝切除後 $1 ， 2 ， 3 ， 4 ， 5$ 日目, 拉よび 1 , 2,3 週間目にインスリン，膵グルカゴン，ソマトス タチン值を radioimmunoassay (RIA)にて，また，血 糖値を glucose oxidase 法5)にて測定した.インスリン については固相化ビーズを用いた測定法6)を用い，膵 グルカゴンについては, 膵グルカゴン特異抗体 OAL123を用いた RIA 7), ソマトスタチンいいては合成ソ マトスタチンを用いて作成した抗体による RIA ${ }^{8)}$ で測 定した.

2. 肝切除後, 1,2 週間目に0. $5 \mathrm{~g} / \mathrm{kg}$ の経静脈的耐 糖能検査を施行し, 前値, $5,15,30,45,60$ 分後ま で，血糖，インスリン执よび萃グルカゴンを前記の方 
法にて測定した。経静脈的耐糖能検査においては血糖 消失率 ( $\mathrm{K}$ 值)，15分での insulinogenic index (I.I)， integrated increased insulin (インスリン分泌増加

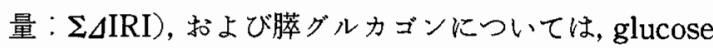
負荷前値の glucose 負荷後15分値に対する比を IRG ratio として表現し, glucoseによる膵グルカゴンの分 泌抑制の程度の指標とした。

3. 肝切除後, 1,2 週間目にペントバルビタール全 身麻酔下に開腹し, 膵右葉尾側部にて膵生検を施行し, 少量の組織を採取し, 10\%中性ホルマリンにて固定後, hematoxylin-eosin 染色法にて, 膵島の変化(膵島の面 積および核数の変化)を，なた peroxidase antiperoxidase (PAP) 染色法によって, 膵島内の A, B, D 細 胞の変化を観察した。膵島については各時期に at ran. dom に200個の膵島についてその面積を顕微鏡写真下 に測定し，また，A，B，D細胞についても，各時期に ついて at randomに200個観察し検討した。

4.なお， 4 頭の成犬に全身麻酔下にて単開腹し, 門 脈本幹にカテーテル插入留置のみを施行し, 肝切除群 と同様の実験操作を加えコントロール群として検討し た.

5. 結果は, 一部を除き, 平均士標準誤差として表わ し, 各グループ間の検討には Student の $\mathrm{t}$ 検定を用い, $\mathrm{p}<0.05$ をって有意差ありと判定した。

\section{結果}

1. 肝切除後, 門脈血中膵ホルモンの変動について は,インスリンは肝切除後, 2,3 日目に $10 \pm 2 \mu \mathrm{U} / \mathrm{ml}$, $9 \pm 3 \mu \mathrm{U} / \mathrm{ml}$ となりコントロール群 $(17 \pm 3 \mu \mathrm{U} / \mathrm{ml}$, $17 \pm 2 \mu \mathrm{U} / \mathrm{ml})$ に比へ，有意に $(\mathrm{p}<0.05)$ 低下した。 ソマトスタチンす肝切除後, 1,2 日目に $57 \pm 8 \mathrm{pg} / \mathrm{ml}$, $75 \pm 12 \mathrm{pg} / \mathrm{ml}$ となりコントロール群 $(128 \pm 26 \mathrm{pg} / \mathrm{ml}$, $142 \pm 16 \mathrm{pg} / \mathrm{ml})$ に比べ有意に低値を示した $(\mathrm{p}<0.05)$. 膵グルカゴンについては, 逆に, 肝切除後， 1,2 , 5 日目に $550 \pm 167 \mathrm{pg} / \mathrm{ml}, 564 \pm 89 \mathrm{pg} / \mathrm{ml}, 544 \pm 118 \mathrm{pg} /$ $\mathrm{ml}$ となり, コントロール群 $(318 \pm 56 \mathrm{pg} / \mathrm{ml}, 325 \pm 94$ $\mathrm{pg} / \mathrm{ml}, 304 \pm 94 \mathrm{pg} / \mathrm{ml})$ に比べ, 有意に（ $\mathrm{p}<0.05 ）$, 高値を示した（図 1a, b, c).しかし血糖値については, 肝切除後, コントロール群と比ベ，有意な变動は示さ なかった（図 2 ).

また，いずれの膵ホルモンも肝切除後 1 週間目まで 著明な変動を示したが, 肝切除後 2 週間目にはコント ロール群と同様の值を示し, 肝切除前に回復する傾向 を示した。

2. 経静脈的耐糖能検查における耐糖能の変化とし
図 1 肝切除後の門脈血中, $\mathrm{a}:$ インスリン, $\mathrm{b}$ : 膵グ ルカゴン, c：ソマトスタチン, の変動(実線：肝切) 除, 破線：対照, $\mathrm{n}=4$, mean $\pm \mathrm{SE}$ )
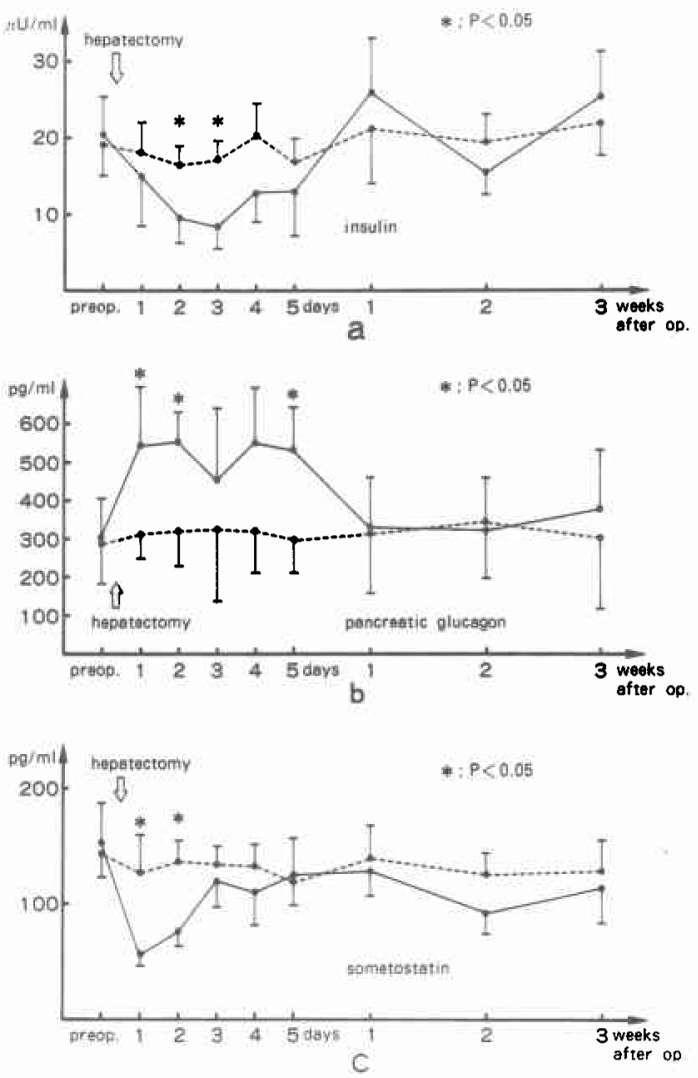

図 2 肝切除後の門脈血中血糖値の変動 (実線 : 肝切 除, 破線：対照, $n=4$, mean $\pm S E$ )

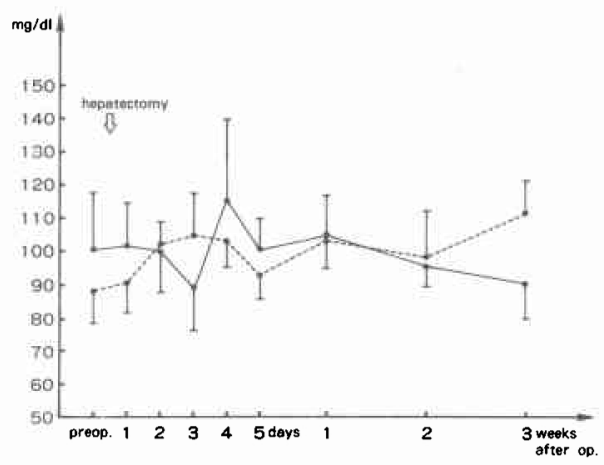

ては, 肝切除後 1 週間目には, glucose 負荷に対するイ ンスリンの反応は低下し，血糖も上昇し，15分值では インスリンは $13 \pm 3 \mu \mathrm{U} / \mathrm{ml}$, 血糖值は $251 \pm 17 \mathrm{mg} / \mathrm{dl}$ と なり,コントロール群（インスリン: $39 \pm 10 \mu \mathrm{U} / \mathrm{ml}$, 
図 3 肝切除前 (上段)，１週間後（中段），２週間後 (下段)の経静脈的耐糖能検査によるインスリン（a）, 血糖 (b) の変動（実線：肝切除, 破線: 対照, $\mathrm{n}=$ 4 , mean $\pm \mathrm{SE}$ )
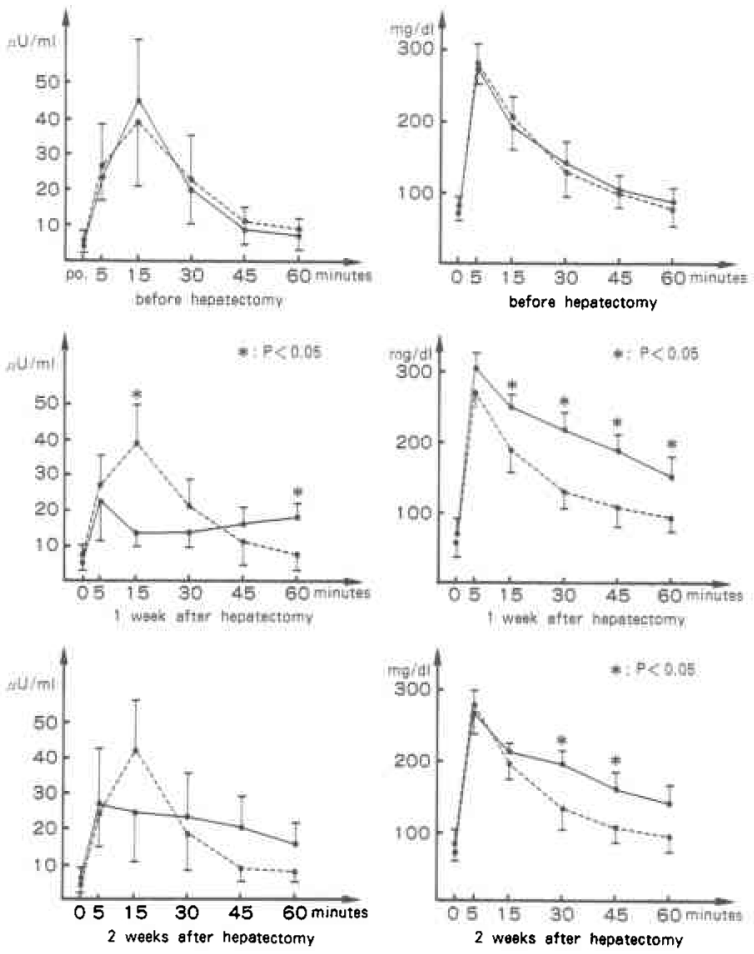

a

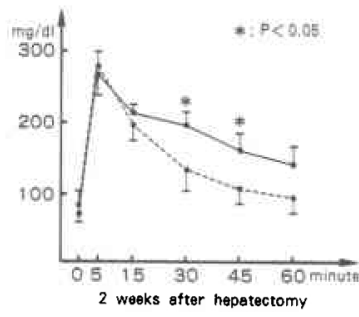

b

血糖値： $190 \pm 28 \mathrm{mg} / \mathrm{dl})$ に比へ，有意な $(\mathrm{p}<0.05)$ 変 化を示し，糖尿病様の值を示した（図 3a, b).

$\mathrm{K}$ 值は肝切除後 1 週間目に0.84士0.18を示し, コン トロール群 $(1.65 \pm 0.11)$ に比べ, 有意に $(\mathrm{p}<0.01)$ 低值を示し, I.I 值は訮切除後 1 時間目に0.06士0.02 と なり,コントロール群 $(0.32 \pm 0.08)$ に比べ, 有意の $(\mathrm{p}<0.01)$ 低値を示し， $\Sigma \Delta I R I$ 女肝切除後 1 週間目に $931 \pm 147 \mu \mathrm{U} \cdot \mathrm{min} / \mathrm{ml}$ となり,コントロール群 $(1,382 \pm 168 \mu \mathrm{U} \cdot \mathrm{min} / \mathrm{ml})$ に比べ有意に $(\mathrm{p}<0.05)$ 低 下したが,これら 3 このパラメーターは肝切除後 2 週 間目にはコントロール群に近づき回復の傾向を示した (図 4a,b,c).

一方, 膵グルカゴンの糖負荷に対する反応は, 肝切 除後 1 週間目には，glucose 負荷に対する分泌抑制が みられず, IRG ratioは0.95土0.08となりコントロー ル群 $(0.76 \pm 0.06)$ に比べ, 有意に $(\mathrm{p}<0.05)$ 高い值 を示したが，これす肝切除後 2 週間目には肝切除前の 状態に回復する傾向を示した（図 $5 \mathbf{a}, \mathbf{b}$ ).
図4肝切除後の血糖消失率 ( $\mathrm{K}$ 值) (a), in sulinogenic index (I.I) (b),インスリン分泌増加量 ( $\Sigma \Delta I R I)(c)$ (白又肝切除, 斜線：対照 $n=4$, mean $\pm \mathrm{SE})$
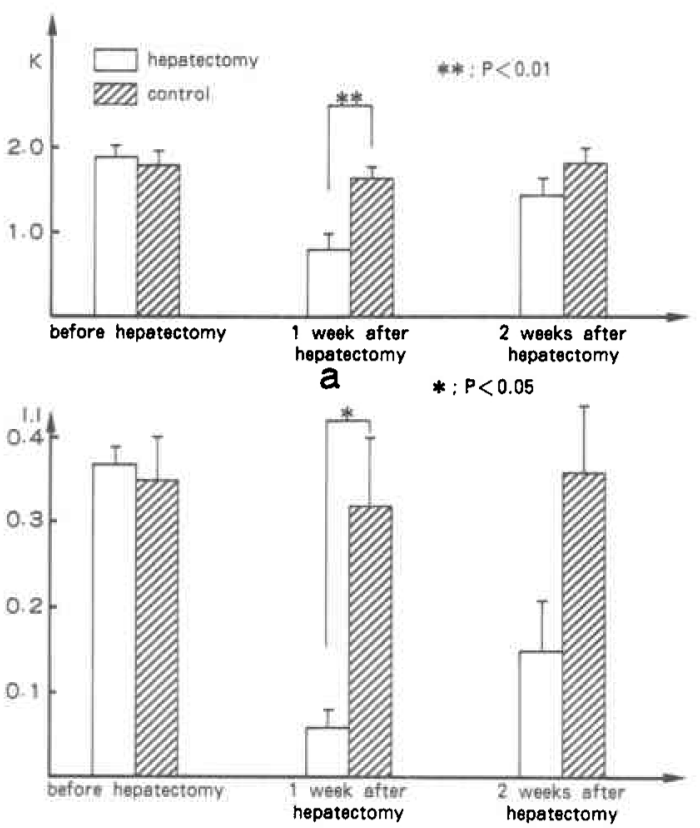

b

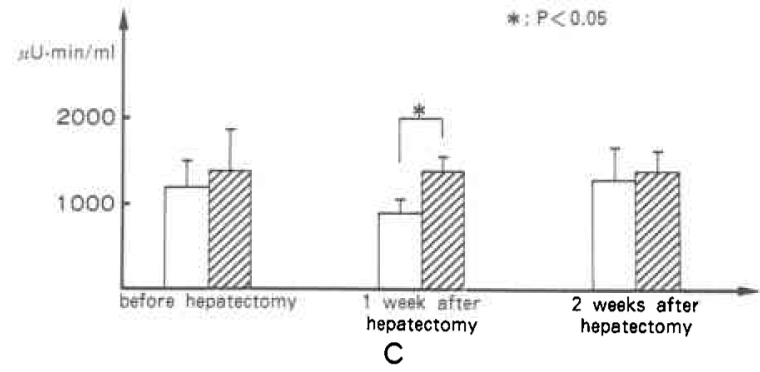

3. 組織学的には,肝切除後 1 週間目には脺島の面積 は $1,085 \pm 39 \mu \mathrm{m}^{2}, \quad 2$ 週間目には $2,342 \pm 177 \mu \mathrm{m}^{2}$ とな り, コントロール群 $\left(712 \pm 45 \mu \mathrm{m}^{2}, 742 \pm 56 \mu \mathrm{m}^{2}\right)$ に比 ベ，有意に（p<0.001）増大し，膵島内の核数も肝切 除後 1 週間目に $24 \pm 18$ 個/島，2㥜間目に69土35個/島 となりコントロール群（18土4 個/島, $22 \pm 8$ 個/島） に比べ有意に増加した（ $<<0.001 ） （$ 図 6a, b)。

$\mathrm{A}$ 細胞については, 肝切除後 1 週間目に, $9 \pm 4$ 個/ 島， 2 週間目に18 8 個/島となりコントロール群( 1 週間目： $6 \pm 2$ 個/島， 2 週間目：5士2 個/島）に比 べ，有意に（p<0.001）増加した，B 細胞は肝切除後 1 週間目に $15 \pm 5$ 個/島， 2 週間目に $26 \pm 10$ 個/島とな 
図 5 肝切除前，1週間後，2週間後の経静脈的耐糖 能検査に対する末梢血グルカゴンの変動.（a）経静 脈的耐糖能検查の前値を 1.0 とした時の変化(実線： 肝切除, 破線 : 対照, $n=4$, 平均値), (b) IRG 比, 糖糖負荷 15 分值/糖負荷前值（白又キ: 肝切除, 斜 線：対照, $n=4$, mean $\pm S E$ )
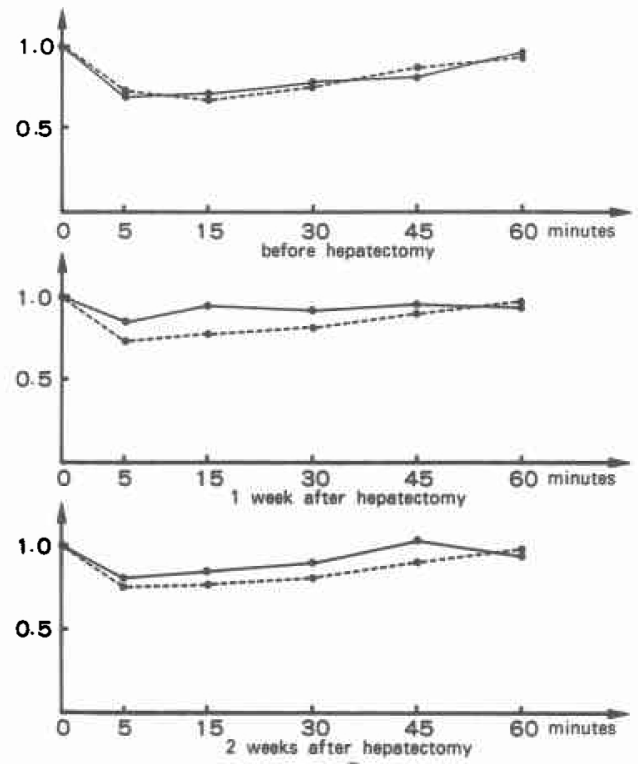

a

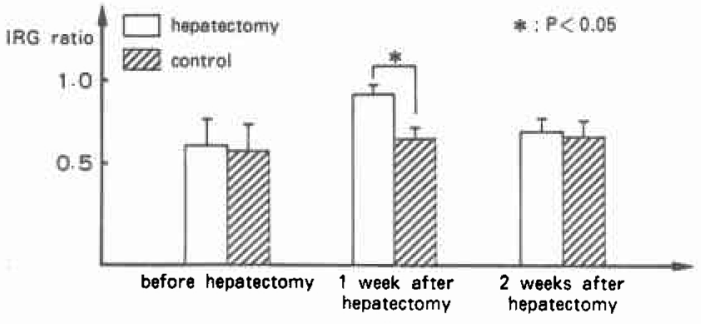

b

クコントロール群( 1 週間目 : $10 \pm 2$ 個/島， 2 週間

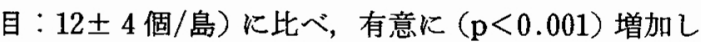
た. D 細胞子同様に, 肝切除後 1 週間目に $12 \pm 5$ 個/島, 2 週間目に15士 4 個/島となり，コントロール群( 1 週 間目： $8 \pm 2$ 個/島， 2 週間目：9 9 個/島)に比べ, 有意に $(\mathrm{p}<0.001)$ 増加したが, 特に $\mathrm{A}$ 細胞の増加率 が著明であった（図 7a, b, c).

\section{考察}

肝切除後の肝再生過程において，膵ホルモンである インスリン，グルカゴンが重要なことは従来より報告 されている1) 3). 門脈血中のインスリン值については, 肝切除後早期には，その值はむしろ低下し，グルカゴ
図 6 (a) 肝切除後の膵島の大きさ（mean士 $\mathrm{SE}, \mathbf{n}=$ $200)$ ，拈よび (b) 膵島の核数 (mean $\pm \mathrm{SD}, \mathrm{n}=200)$ （白ヌキ：肝切除，斜線：対照)
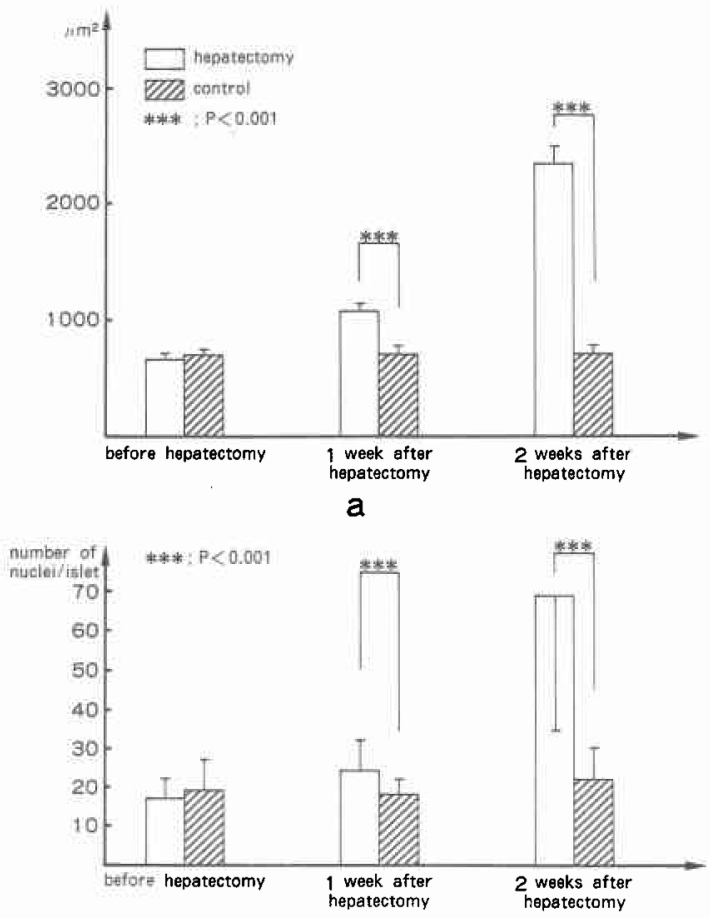

b

ン值については，逆に上昇するという報告が多い が910), 今回のわれわれの実験の結果もそれらの報告 と同様の傾向を示したが，その傾向は汗切除後 1 ～ 週間持続するという新たな知見を得ることができた。 このことは，肝切除後の膵内分泌系に対する影響を観 察する場合, 数週間の観察期間が必要なことを示唆し た. 肝切除後には, 組織学的, 形態学的には, 膵島の 増大とともに，その構成要素である A, B, D 細胞のす ベての増加が認められ, 形態学的には, 肝切除後の脺 内分泌系は機能六進状態を示唆させた。一方，経静脈 的耐糖能検査による glucose 負荷に対しての反応をみ ると，末梢血では高血糖とともにインスリンの低反応 性が示された。

このよらに, インスリンは形態面と機能面でのかい 離がみとめられた。膵グルカゴンは, 逆に glucose 負荷 に対しての分泌抑制反応を喪失したような変動を示し た、膵グルカゴンに関しては，訮切除後その門脈血中 での值は高值に維持されて㧍り, 組織学的にも, 肝切 除後, 膵島内の A 細胞数も増加した. 肝切除後早期に 
図 7 肝切除後の膵島の $\mathrm{A}$ 細胞 (a), B 細胞 (b), D 細 胞（c），(白又キ: 肝切除, 斜線：対照, $n=200$, mean $\pm \mathrm{SD}$ )
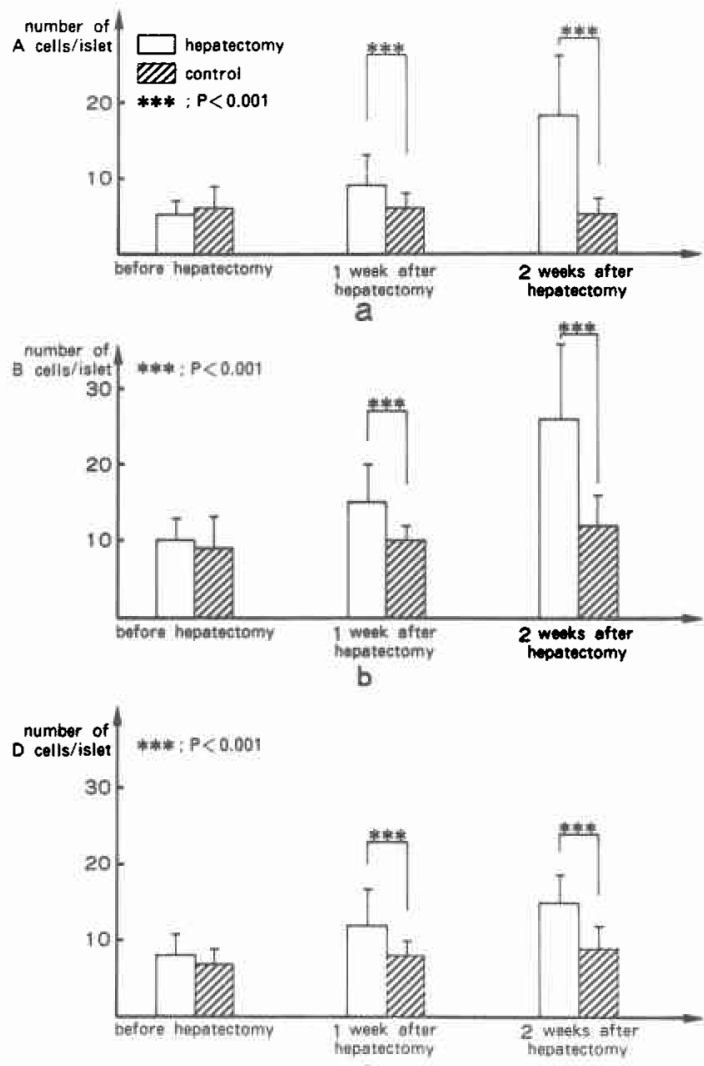

C

は, glucose 負荷に対する膵グルカゴンの反応が抑制 されないことは，肝切除後の残肝でのグルカゴンの取 込及の促進 ${ }^{110111)}$ ，すなわち, 残肝での hepatotrophic factorとしての消費が高まっていることを示してい ると考克られる、一方，インスリンの形態面と機能面 でのかい離に対しては, insulo-acinar axis の存在が考 えられる.以前より, 膵島の近傍の膵腺房細胞は periinsular acinar cell と呼ばれ, 膵島より遠位の膵腺房 細胞（tele-insular acinar cell）より大きいことが報 告1213)されている.

さらに, 解剖学的にも, 膵島から直接に膵腺房細胞 にいたる膵内局所門脈系 (insulo-acinar portal system)の存在 ${ }^{14)}$ が証明されており, 膵腺房細胞ではイン スリンレセプターもみとめられる(1516)ことからも, 膵 ホルモンは膵腺房細胞の機能維持のために重要な役 割17)を演じていると考えらえる。特に,インスリンに関
しては，膵腺房細胞での膵消化酵素，とりわけ， amylase の合成に非常に重要であり，糖㽷病患者では 脺内の amylase の含有量も減少しているといわれて いる(18)ことからも，膵外分泌系の機能維持に対するイ ンスリンの果す役割は大きいと思われる。

このよらに,インスリンは膵外分泌系の機能維持, および, 肝切除後の残肝における hepatotrophic factor として，また energy charge の維持 ${ }^{19}$ のために非 常に重要と考完られた。

さらに，残肝の肝再生過程で，肝妡除前の重量に回 復するのに当然必要とされる糖質を主体とした種々の 栄養素およびェネルギー源の消化管よりの消化・吸収 を目的とした脺腺房細胞中での amylase の合成と分 泌を高めるためにもインスリンは, insulo-acinar axis を介して，多量に消費されると考えられた。

ひいてはこのことが肝切除後早期における耐糖能の 低下を生みたしていると考えられた。

また，肝切除後には，膵島の構成要素である A， B， $\mathrm{D}$ 細胞のすべてが増加することがみとめられ，このう $ち \mathrm{~A}, \mathrm{~B}$ 両細胞は, hepatotrophic factor として, た膵腺房細胞の譏能維持のために合目的的に増加する と考えられるが，D細胞の増加の理由については，現 時点では明らかではない，糖尿病では，D細胞が増加 するとの報告20)もあり，肝切除後に招いてもソマトス タチンは B 細胞からのインスリン分泌を抑制し, 膵グ ルカゴンの高値の維持とあいまって高血糖の形成に関 与し，ひいては肝切除後早期の耐糖能の低下の一因に なっていると思われた。このように, 肝切除後の膵内 分泌系では, 膵ホルモン動態拉よび, 膵島の形態学的, 機能的変化からみて, 数週間にわたり複雑な変化が生 じていることが示唆された，今後は，膵外分泌系と消 化管ホルモンを含めた消化管と膵内・外分泌系との相 関についての研究が必要と思われた。

\section{まとめ}

1.イヌに括いて, 約 $40 \%$ の肝切除後早期には, 門脈 血中インスリンとンマトスタチン値は低下したが，膵 グルカゴン值は逆に上昇を示し，その傾向は肝切除後 約 2 週間まで持続した。

2. 肝切除後, 膵島の面積は増大し, その構成要素で ある A， B，D細胞数もすべて増加したが，特に， A 細 胞数の増加率が高かった。

3. 肝切除後早期では, 経静脈的耐糖能検查による glucose 負荷に対する末梢でのインスリンの反応は低 下し, 逆に, 膵グルカゴンはglucose 負荷に対しての分 
泌抑制反応がみとめられなかった。

以上より, 肝切除後には, 脺グルカゴンは hepatotrophic factorとして，インスリンはさらに膵外分泌系を 介して残肝に影響を与えていると考光られ，それらの インスリンとグルカゴンの反応はまた肝切除後早期の 耐糖能の低下の一因とも考えられた。ソマトスタチン 含有細胞である D 細胞の増加も肝切除後早期の耐糖 能の低下の一因となっている可能性が示唆された。

\section{文献}

1) Price JB, Takeshige $K, \operatorname{Max} M H$ et al: Glucagon as the portal factor modifying hepatic regeneration. Surgery 72:74-82, 1972

2) Bucher NLR, Swaffield MN : Regulation of hepatic regeneration in rats by synergistic action of insulin and glucagon. Proc Natl Acad Sci $72: 1157-1160,1975$

3) Starzl TE, Francavilla A, Porter KA et al : The effect of splanchnic viscera removal upon canine liver regeneration. Surg Gynecol Obstet 147 : 193-207, 1978

4) Richman RA, Claus TH, Pilkis SJ et al: Hormonal stimulation of DNA synthesis in primary cultures of adult rat hepatocytes. Proc Natl Acad Sci 73 : 3589-3593, 1976

5) Bruss ML, Black AL: Enzymatic microdetermination of glycogen. Anal Biochem 84 : 309 - 312,1978

6）兵頭常一, 難波 修, 中村公一汪か：固相化ビーズ を用いる血中 IRI 測定法の臨床応用一特に従来の 2 抗体法との比較について一. ホルモンと臨 $31: 1129-1138,1983$

7) Nishino $T$, Kodaira $T$, Shin $S$ et al: Glucagon radioimmunoassay with use of antiserum to glucagon C-terminal fragment. Clin Chem 27 : $1690-1697,1981$

8）山口建, 安達 勇, 宮川澄子ほか: Somatostatin 産生腫瘍における大分子Somatostatinの 存在について. 消化管ホルモン研究会編, 消化管ホ ルモン ( I ), 医学図書出版, 東京, 1981, p228-235

9) Caruana JA, Gage AA: Increased uptake of insulin and glucagon by the liver as a signal for regeneration. Surg Gynecol Obstet 150 :
$390-394,1980$

10) Leffert HL, Koch KS, Moran $T$ et al: Hormonal control of rat liver regeneration. Gastroenterology $76: 1470-1478,1979$

11) Watanabe A, Higashi $T$, Hayashi $S$ et al: Insulin and glucagon in the portal and peripheral blood in liver-injured and partially hepatectomized rats. Gastroenterol Jpn 17 : $36-41,1982$

12) Hellmann BA, Wallgren A, Peterson B : Cytological characteristics of the exocrine pancreas cells with regards to their position in relation to the islet of Langerhans. Acta Endocrinol 39:465-473, 1962

13) Bendayan M: Morphological and immunohistochemical characterization of peri-insular and tele-insular acinar cells in the rat pancreas. Eur J Cell Biol 36 : 263-268, 1985

14) Fujita $T$ : Insulo-acinar portal system in the horse pancreas. Arch Histol Jpn 35 : 161-171, 1973

15) Korc M, Sankaran H, Wang KY et al : Insulin receptors in isolated mouse pancreatic acini. Biochem Biophys Res Commun 84 : 293-299, 1978

16) Sjodin L, Holmberg K, Leyden A: Insulin receptors on pancreatic acinar cells in guinea pigs. Endocrinology 115:1102-1109, 1984

17) Williams JA, Goldfine ID: The insulopancreatic acinar axis. Diabetes $34: 980-985$, 1985

18) Korc M, Owerbach D, Quinto C et al : Pancreatic islet-acinar cell interaction: Amylase messenger RNA levels are determined by insulin. Science $213: 351-353,1981$

19) Ozawa K, Yamada T, Honjo I et al: Role of insulin as a portal factor in maintaining the viability of liver. Ann Surg 180:716-719, 1974

20) Orch L, Baetens D, Rufener C et al : Hypertro. phy and hyperplasia of somatostatin containing D cells in diabetes. Proc Natl Acad Sci USA $73: 1338-1342,1976$ 